\title{
Histomorphometric analysis of gonads of green turtles (chelonia mydas) stranded on the coast of Espírito Santo state, Brazil
}

[Análise histomorfométrica das gônadas de tartarugas verdes (Chelonia Mydas) provenientes de encalhe no litoral do Espírito Santo, Brasil]

\author{
G. Failla ${ }^{1}$, A. Calais Júnior ${ }^{2}$, L. Pavanelli ${ }^{3}$, L.C. Nunes ${ }^{4}$
}

${ }^{1}$ Veterinário residente - Universidade Federal Fluminense - Niterói, RJ

${ }^{2}$ Aluno de pós-graduação - Universidade Federal do Norte Fluminense - Campos dos Goytacazes, RJ

${ }^{3}$ Médica veterinária autônoma - Vitória, ES

${ }^{4}$ Universidade Federal do Espírito Santo - Alegre, ES

\begin{abstract}
Studies on reproduction in sea turtles are important due to its life cycle, migratory patterns, high juvenile mortality and environmental impacts. This study aimed to analyse histomorphometrically gonads of C. mydas from the coastline of the Espírito Santo State, Brazil. Ovaries and testicles were collected between 2014 and 2015 from stranded animals. The material was fixed in formalin 10\%, assessed macroscopically and processed for histomorphometrical evaluation. Gonads from 34 individuals were evaluated, twentyfour females and ten males. Macroscopic sexual identification presented $100 \%$ accuracy confirmed by histology. Sexual dimorphism was observed in one individual, which was considered as adult $(\mathrm{CCL}=1.023 \mathrm{~m})$. Microscopy of female gonads revealed predominant previtellogenic follicles; oocyte diameter ranged between $161 \mu \mathrm{m}$ and $750 \mu \mathrm{m}$ and a positive correlation between ovarian length, largest oocyte and CCL was found. In males, autolysis was verified in five individuals. Viable testicles revealed predominant spermatogonia, primary spermatocytes and Sertoli cells in the seminiferous tubules and, Leydig cells and fibroblasts in the stroma. There was a positive correlation between tubular diameter and CCL and testicle length and CCL. Maturation of stromal tissue and a positive correlation between tubular lumen and CCL were also observed. Gonad development is proportional to individual growth.
\end{abstract}

Keywords: follicular development, testis development, histology, ovary, testicle

\section{RESUMO}

Estudos em reprodução de tartarugas marinhas são importantes devido ao ciclo de vida, ao padrão migratório, à alta mortalidade juvenil e aos impactos ambientais. Objetivou-se analisar histomorfometricamente gônadas de C. mydas no litoral do Espírito Santo. Foram coletados ovários e testículos dessa espécie, entre 2014 e 2015. O material foi fixado em formol a 10\% e avaliado macroscopicamente. Em seguida, foi processado para avaliação histomorfométrica. Foram avaliadas gônadas de 34 indivíduos, 24 fêmeas e 10 machos. Verificaram-se 100\% de acurácia na identificação sexual à macroscopia, confirmada pela histologia. Observou-se dimorfismo sexual em um macho, que foi considerado adulto (CCC=1,023m). A microscopia dos ovários revelou folículos pré-vitelogênicos, cujos ovócitos apresentaram diâmetro médio entre $161 \mu \mathrm{m}$ e $750 \mu \mathrm{m}$. Houve correlação positiva entre comprimento ovariano e diâmetro do maior ovócito e CCC. Nos machos, verificou-se autólise em cinco indivíduos. Os testículos viáveis revelaram espermatogônias, espermatócitos primários e células de Sertoli nos túbulos seminíferos, além de células de Leydig e fibroblastos no estroma. Houve correlação positiva entre diâmetro tubular e CCC e comprimento testicular e CCC. Verificou-se maturação do tecido estromal e correlação positiva entre o diâmetro do lúmen tubular e o CCC. Verifica-se que o desenvolvimento das gônadas é proporcional ao crescimento dos indivíduos.

Palavras-chave: desenvolvimento folicular, desenvolvimento testicular, histologia, ovários, testículos

Recebido em 15 de agosto de 2016

Aceito em 3 de dezembro de 2016

E-mail: giuliano.failla@gmail.com 


\section{INTRODUCTION}

The green sea turtle, Chelonia mydas, is classified as threatened under high risk of extinction on the IUCN Red List (International..., 2014) and as vulnerable, according to the Ordinance $n^{\circ} 444$ from the Brazilian Ministry of Environment (Brasil, 2014), which highlights the extreme importance of reproduction in the perpetuation of the species.

Sexing juvenile sea turtles is difficult due to sexual dimorphism occurring only at sexual maturity (Wibbels, 2003). Therefore, the most commonly used methods for sexual identification in live beings during this stage of life are by endocrine hormones essays and laparoscopy, while in dead animals sex can be determined by macroscopic observation of gonads (Lazar et al., 2008).

Gonadal histomorphometry in C. mydas has been described for diverse life stages of the turtle (Aitken et al., 1976; Miller and Limpus 2003; Pérez et al., 2010); however, no study specifically aimed gonad development in free living post-neonatal and juvenile specimens and the processes that occur during the pelagic phase still remain unknown (Pérez-Bermúdez et al., 2012). In addition, follicular development has not been described for this species.

Certain toxic inorganic elements and xenobiotic compounds are known for causing endocrine disruption in humans and animals (Kortenkamp et al., 2011). In fish, exposure to pollution, for short and long periods and also depending on stage of ovarian and/or follicular development, may result in reduction in fertility leading to decreases in the gonadosomatic index (GSI), smaller and less developed oocytes, smaller number of mature oocytes and increases in the quantity of atretic follicles (Kime, 1995). Decreases in nucleic acids, protein content and enzymatic activity by alkaline phosphatase after exposure to malathion, an organophosphate insecticide, were described by Ansari and Kumar (1987). Exposure to heavy metals, cadmium and mercury was also reported causing decreases in fish fertility (Ram and Sathyanesan 1986; Victor et al., 1986; Ram and Sathyanesan, 1987; ElEbiary et al., 2013).
There are no records of the relation between the exposition to pollutants or inorganic toxics and the reproductive system of sea turtles. However, many authors have suggested the relation between the exposition to pollutants and increases in susceptibility to diseases in sea turtles (Aguirre et al., 1994; Keller et al., 2006; Camacho et al., 2013).

Currently, there are no available studies in the literature that relate gonadal histology of marine turtles with the environment. The present study proposed to assess morphologically and morphometrically ovaries and testicles of sea turtles from the species Chelonia mydas that inhabit the coast line of Espírito Santo State; classify these individuals as for their sexual maturity and gonadal development, relating those parameters with individual growth.

\section{MATERIAL AND METHODS}

Ovaries and testes of green turtles, C. mydas, were obtained during the period comprising April-2014 to April-2015. , from stranded animals collected by the Project Monitoring of Beaches and Bays of Campos and Espírito Santo ("Projeto de Monitoramento Praias e Bacias de Campos e do Espírito Santo"), which is a demand by the process of environmental licensing conducted by the Brazilian Institute of Environment (IBAMA - Instituto Brasileiro do Meio Ambiente). Corpses were sent to the veterinary base of CTA Meio Ambiente located in Anchieta - ES for necroscopy.

Samples were fixed in formalin $10 \%$ and sent to the Laboratory of Animal Pathology from the Federal University of Espírito Santo for analysis. Each gonad was initially assessed macroscopically and measurements of length and width were taken with a caliper rule. Then, gonads were submitted to histological routine processing and Hematoxylin-Eosin staining method. Histologic analysis was executed with a microscope linked to $\mathrm{CCB}$ capture camera (Sony) and Image Pro Plus image analysis software.

For each female, ovaries were morphologically assessed, the diameter of the three largest oocytes was determined using a $20 \mathrm{X}$ objective lens and then a mean value was obtained per individual. For male evaluation, each testis was 
microscopically assessed and the main cellular types were identified and quantified. From each individual, ten seminiferous tubules were analysed and a mean value was calculated for each cellular type, expressed in percentage.

Testicular morphology was done measuring the diameter of three seminiferous tubules, as well for the tubular lumen, with a 40X objective lens, and a mean value was obtained for each of these parameters per individual.

Data from necropsy files of each turtle, such as Curvilinear Carapace Length (CCL), Curvilinear Carapace Width (CCW), Body Mass (BM), Body Score (BS), stranding site and signs of anthropic interaction were also collected.

Descriptive statistic was utilized for epidemiological data and values were expressed in percentage. Parametric Pearson correlation coefficient was used to assess the association between ovary length and CCL, largest oocyte diameter and CCL, testicular length and CCL, and tubular diameter and CCL.

This experimental protocol was conducted under the authorization for scientific activities number 39329-1, by the Biodiversity Information System (SisBio) linked to the Chico Mendes Institute for Conservation of Biodiversity (Instituto Chico Mendes de Conservação de Biodiversidade - ICMBio) from the Brazilian Ministry of Environment (Ministério do Meio Ambiente - MMA).

\section{RESULTS}

During this study, thirty-four gonads were collected, of which twenty-four (70.59\%) were female gonads and ten $(29.41 \%)$ were male.

In the macroscopic examination of the ovaries, the average length of the ovaries varied between $2.57 \mathrm{~cm}$ and $7.90 \mathrm{~cm}$ and the average width between $0.14 \mathrm{~cm}$ and $1.14 \mathrm{~cm}$ (Table 1 ).

In the microscopy of the female gonads, eight individuals could not be assessed due to tissue autolysis. Histomorphologic assessment of the ovaries showed germinal epithelium, oogonia (primordial oocytes), previtellogenic follicles and stroma (Figure 1A, 1B). The follicles presented nucleus, ooplasm, zona pellucida, a single layer of follicular cells, covered by theca cells (Figure 1C). There were observed no corpus luteum nor corpus albicans.

Morphometry revealed the largest observed oocyte had a diameter between $106 \mu \mathrm{m}$ and $805 \mu \mathrm{m}$.

Females presented CCL and CCW between $0.273 \mathrm{~m}$ and $0.575 \mathrm{~m}$ and between $0.271 \mathrm{~m}$ and $0.513 \mathrm{~m}$, respectively. Body mass varied from 2.540 to $16.100 \mathrm{~kg}$ (Table 1). Ten, $41.67 \%$, turtles presented "good" body score, while three $(12.5 \%)$ had "average" score and eleven $(45.83 \%)$ had "poor" body score.

A positive correlation was found between CCL and the average diameter of the largest oocytes, which had a correlation coefficient of 0.719 . There was also a moderate positive correlation between the average ovary length and CCL by individual, which had a coefficient of 0.652 . Body mass and the largest oocyte also showed a moderate positive correlation, although with a higher value, 0.698 .

Microscopic analysis of testes revealed mean length varying between $2.90 \mathrm{~cm}$ and $9.94 \mathrm{~cm}$ and mean width between 0.17 and 3.91 (Table 2).

Among the individuals utilized in this study, five presented testicular samples with advanced autolysis, which made impossible the histologic assessment.

Histologically, the interstitial space is composed of immature, loose connective tissue, mainly constituted by fibroblasts (small nucleus and oval shaped) and collagen sparsely distributed and Leydig cells (round shaped nucleus and lipid droplets in the cytoplasm). Sertoli cells (oval shaped nucleus), spermatogonia (large, round nucleus) and primary spermatocytes (purple coloured cells with large nucleus) were observed In the seminiferous tubules. Spermatogonia, Sertoli cells and primary spermatocytes were found at $88.08 \%, 7.18 \%$ and $4.74 \%$, respectively (Figure 1E, 1F). 
Failla et al.

Table 1. Biometric and morphometric data of gonads and oocytes from C. mydas females during the period from April/2014 to April/2015 in Espírito Santo State, Brazil

\begin{tabular}{cccccccc} 
Individual & $\begin{array}{c}\text { CCL } \\
(\mathrm{m})\end{array}$ & $\begin{array}{c}\text { CCW } \\
(\mathrm{m})\end{array}$ & $\begin{array}{c}\text { Weight } \\
(\mathrm{kg})\end{array}$ & $\begin{array}{c}\text { Mean Ovary } \\
\text { Length }\end{array}$ & $\begin{array}{c}\text { Mean Ovary } \\
\text { Width }\end{array}$ & $\begin{array}{c}\text { Mean largest } \\
\text { oocyte diameter }\end{array}$ & SD \\
\hline 1 & 0.369 & 0.341 & 4.540 & 5.65 & 0.95 & - & - \\
2 & 0.395 & 0.348 & 8.000 & - & 0.85 & - & - \\
3 & 0.349 & 0.372 & 4.250 & 5.50 & 0.50 & - & - \\
4 & 0.273 & 0.271 & 2.540 & 5.10 & 0.50 & 161.33 & 29.30 \\
5 & 0.445 & 0.414 & 11.570 & 7.90 & 1.40 & 750.33 & 47.72 \\
6 & 0.426 & 0.413 & 6.240 & 6.40 & 1.15 & 388.67 & 19.76 \\
7 & 0.351 & 0.323 & 3.930 & - & 0.60 & 186.33 & 32.93 \\
8 & 0.385 & 0.361 & 6.610 & 6.05 & 0.80 & 352.00 & 32.60 \\
9 & 0.336 & 0.327 & 3.000 & 5.10 & 0.35 & - & - \\
10 & 0.330 & 0.304 & 3.830 & 4.30 & 0.80 & 251.67 & 7.37 \\
11 & 0.555 & 0.491 & 11.750 & 6.95 & 0.85 & - & - \\
12 & 0.476 & 0.435 & 7.820 & 4.41 & 0.44 & 442.00 & 144.88 \\
13 & 0.422 & 0.366 & 8.790 & 6.03 & 0.57 & - & - \\
14 & 0.331 & 0.296 & 4.350 & 2.57 & 0.19 & 323.33 & 35.64 \\
15 & 0.303 & 0.282 & 3.950 & 3.13 & 0.14 & 149.00 & 45.83 \\
16 & 0.345 & 0.319 & 2.620 & 5.28 & 0.44 & - & - \\
17 & 0.365 & 0.361 & 4.770 & 6.11 & 0.72 & 365.67 & 64.69 \\
18 & 0.396 & 0.369 & 6.380 & 5.54 & 1.03 & - & - \\
19 & 0.312 & 0.281 & 2.830 & 4.25 & 0.74 & 430.00 & 5.57 \\
20 & 0.371 & 0.359 & 4.100 & 3.52 & 0.86 & 513.33 & 35.39 \\
21 & 0.352 & 0.315 & 5.100 & 3.60 & 0.41 & 209.67 & 15.01 \\
22 & 0.316 & 0.289 & 3.700 & 3.64 & 0.45 & 223.33 & 36.64 \\
23 & 0.575 & 0.513 & 16.100 & 7.57 & 1.14 & 582.00 & 4.58 \\
24 & 0.431 & 0.384 & 6.700 & 4.63 & 0.63 & 418.67 & 20.65 \\
\hline
\end{tabular}

SD: Standard Deviation.

CCL and CCW are demonstrated in meters and body mass in kilograms. Mean length and width are displayed in centimetres while mean diameter and SD are showed in micrometres. (-) measurements were not obtained.

Table 2. Biometric and morphologic data of male C. mydas testicles collected during the period from April/2014 to April/2015 from April/2014 to April/2015 in Espírito Santo, Brazil

\begin{tabular}{ccccccccc} 
Individual & $\begin{array}{c}\text { CCL } \\
(\mathrm{m})\end{array}$ & $\begin{array}{c}\text { CCW } \\
(\mathrm{m})\end{array}$ & $\begin{array}{c}\text { Weight } \\
(\mathrm{kg})\end{array}$ & $\begin{array}{c}\text { Mean } \\
\text { testicular } \\
\text { length }(\mathrm{cm})\end{array}$ & $\begin{array}{c}\text { Mean } \\
\text { testicular } \\
\text { width }(\mathrm{cm})\end{array}$ & Sg \% & St \% & Cs\% \\
\hline 1 & 0.346 & 0.324 & 3.61 & 3.55 & 0.50 & 88.82 & 4.12 & 7.06 \\
2 & 0.302 & 0.283 & 2.15 & 2.90 & 0.45 & 82.65 & 6.89 & 10.47 \\
3 & 0.356 & 0.317 & 4.74 & 5.71 & 0.17 & - & - & - \\
4 & 0.536 & 0.472 & 12.23 & 5.77 & 0.55 & - & - & - \\
5 & 0.338 & 0.296 & 2.85 & 3.25 & 0.38 & 87.98 & 3.83 & 8.20 \\
6 & 0.436 & 0.41 & 6.7 & 4.82 & 0.48 & 92.93 & 3.66 & 3.42 \\
7 & 1.023 & 0.969 & $*$ & 9.94 & 3.91 & - & - & - \\
8 & 0.364 & 0.341 & 5.6 & 4.44 & 0.51 & 88.02 & 5.21 & 6.77 \\
9 & 0.411 & 0.376 & 5.4 & 3.65 & 0.70 & - & - & - \\
10 & 0.331 & 0.287 & 3.8 & 3.28 & 0.41 & - & - & - \\
\hline
\end{tabular}

$\mathrm{Sg}=$ spermatogonia; $\mathrm{St}=$ spermatocytes; $\mathrm{Cs}=$ Sertoli cells. (-) Parameters could not be measured due to tissue autolysis. (*) Parameter not obtained. 


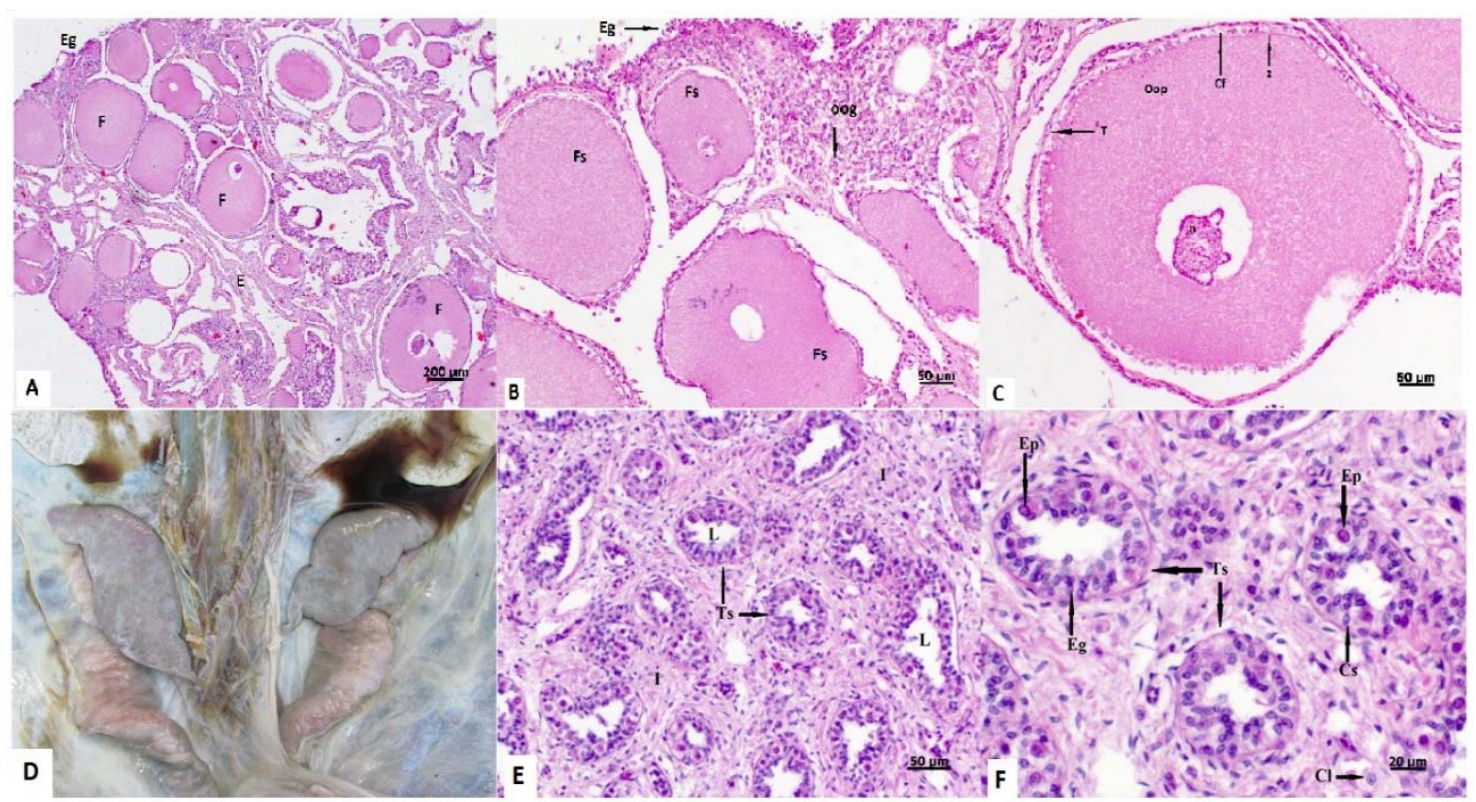

Figure 1. Photomacrography and photomicrography of C. mydas gonads. A): previtellinic follicles (F), estroma (E), germ epithelium (Eg) $(\mathrm{Bar}=200 \mu \mathrm{m})$. B): Nucleus (n), ooplasm (Oop), primordial oocytes $(\mathrm{Oog})(\mathrm{Bar}=50 \mu \mathrm{m}) . \mathrm{C})$ : Previtellogenic follicle, nucleus $(\mathrm{N})$, ooplasm (Oop), zona pelucida $(\mathrm{Z})$ follicular cells (Cf) and teca cells (T). The asterisks indicate processing artefacts (Bar $=50 \mu \mathrm{m})$. D): Testes of an adult $C$. mydas male individual. Exposition of the abdominal cavity containing lungs on the superior portion of the image and caudally to these are located the testes, followed by the vas deferens (pinkish colour). The testicular tissue presented a grey-salmon colour and smooth surface. A segment of the epididymis is observed laterally and under the right testicle (left side of the image). E): Immature connective tissue in the interstitial (I); lumen (L) of seminiferous tubules (Ts) $($ Bar $=50 \mu \mathrm{m})$. F): Seminiferous tubules, Leydig cells $(\mathrm{Cl})$, spermatogonia $(\mathrm{Eg})$, primary spermatocytes $(\mathrm{Ep})$ and Sertoli cells $(\mathrm{Cs})(\mathrm{Bar}=20 \mu \mathrm{m})$. HE stain method.

Morphometry revealed that the seminiferous tubules and lumen mean diameter varied from $33.154 \mu \mathrm{m}$ to $57.327 \mu \mathrm{m}$ and $2.162 \mu \mathrm{m}$ to $21.957 \mu \mathrm{m}$, respectively.

CCL ranged from $0.302 \mathrm{~m}$ to $1.023 \mathrm{~m}$. The later presented male secondary sexual characteristics, however, it also presented advanced tissue autolysis and microscopic assessment was not possible. Table 2 shows biometric and morphologic data obtained from male individuals.

The correlation coefficient between mean testicular length and CCL was 0.937. The correlation coefficient between tubules diameter and CCL was 0.626. Interestingly, the largest individuals presented larger seminiferous tubules, although the smallest tubules were not found in the smallest individual.
Beyond those data, stranding site and signs of anthropic interaction were also obtained (Table 3 ). Thirteen animals showed signs of human interaction $(38.23 \%)$ and the majority of strandings occurred in Vitória and Guarapari municipalities.

\section{DISCUSSION}

In this study samples from male and female individuals in the proportion of 2.4:1 were obtained. In studies on sea turtle stranding patterns done on the Brazilian northeast coast, in the State of Paraíba, $71 \%$ of the total of stranded specimens was female (Poli et al., 2014). In that same study, when only observed Chelonia mydas, $72.5 \% \quad(\mathrm{n}=66) \quad$ were females. Predominance of stranded females was also reported by Mascarenhas et al. (2005), Ceriane and Wyneken (2007) and Grossman et al. (2007). 
Table 3. Stranding site, sex and signs of anthropic interaction of C. mydas individuals collected during the period between April/2014 and April/2015 in Espírito Santo State, Brazil

\begin{tabular}{|c|c|c|c|}
\hline Individual & Local & Sex & Anthropic interaction \\
\hline 1 & Praia do Sauê - Aracruz/ES & $\mathrm{F}$ & $\mathrm{N}$ \\
\hline 2 & Praia do Suá - Vitória/ES & $\mathrm{F}$ & $\mathrm{Y}$ \\
\hline 3 & Bacutia - Guarapari/ ES & $\mathrm{F}$ & $\mathrm{N}$ \\
\hline 4 & Pau Grande - Piúma/ES & $\mathrm{F}$ & $\mathrm{Y}$ \\
\hline 5 & Curva da Jurema - Vitória/ES & M & $\mathrm{N}$ \\
\hline 6 & Conchas/Pelotas - Guarapari/ES & $\mathrm{F}$ & $\mathrm{Y}$ \\
\hline 7 & Barra do Sahy - Aracruz/ES & $\mathrm{F}$ & $\mathrm{N}$ \\
\hline 8 & Praia da Piúma - Piúma/ES & $\mathrm{F}$ & $\mathrm{Y}$ \\
\hline 9 & Parati - Anchieta/ES & $\mathrm{F}$ & $\mathrm{N}$ \\
\hline 10 & Iate Clube - Vitória/ES & $\mathrm{F}$ & $\mathrm{N}$ \\
\hline 11 & Boa Vista do Sol/ES & $\mathrm{F}$ & $\mathrm{Y}$ \\
\hline 12 & Iante Clube - Vitória/ES & $\mathrm{F}$ & $\mathrm{N}$ \\
\hline 13 & Praia dos Ventos - Guarapari/ES & M & $\mathrm{N}$ \\
\hline 14 & Itaipava - Itaipava/ES & $\mathrm{F}$ & $\mathrm{N}$ \\
\hline 15 & Curva da Jurema - Vitória/ES & $\mathrm{F}$ & $\mathrm{N}$ \\
\hline 16 & Praia das Castanheiras - Anchieta/ES & M & $\mathrm{N}$ \\
\hline 17 & Meaípe - Guarapari/ES & $\mathrm{F}$ & $\mathrm{N}$ \\
\hline 18 & Praia do Riacho - Guarapari/ES & $\mathrm{F}$ & $\mathrm{Y}$ \\
\hline 19 & Praia da Barra - Marataízes/ES & M & $\mathrm{N}$ \\
\hline 20 & Iate Clube - Vitória/ES & $\mathrm{F}$ & $\mathrm{N}$ \\
\hline 21 & Curva da Jurema - Vitória/ES & M & $\mathrm{Y}$ \\
\hline 22 & Inhaúma - Anchieta/ES & $\mathrm{F}$ & $\mathrm{U}$ \\
\hline 23 & Praia das Castanheiras - Guarapari/ES & $\mathrm{F}$ & $\mathrm{U}$ \\
\hline 24 & Gamboa - Itapemirim/ES & M & $\mathrm{Y}$ \\
\hline 25 & Marobá - Presidente Kennedy/ES & M & $\mathrm{U}$ \\
\hline 26 & Guaibura - Guarapari/ES & $\mathrm{F}$ & $\mathrm{U}$ \\
\hline 27 & Colônia - Marataízes/ES & $\mathrm{F}$ & $\mathrm{U}$ \\
\hline 28 & Castanheira - Anchieta/ES & $\mathrm{F}$ & $\mathrm{Y}$ \\
\hline 29 & Praia do Centro - Marataízes/ES & $\mathrm{F}$ & $\mathrm{Y}$ \\
\hline 30 & Praia das Neves - Presidente & $\mathrm{F}$ & $\mathrm{U}$ \\
\hline 31 & Curva da Jurema - Vitória/ES & $\mathrm{F}$ & $\mathrm{Y}$ \\
\hline 32 & Caculucage - Marataízes/ES & M & $\mathrm{U}$ \\
\hline 33 & Itaipava - Itapemirim/ES & M & $\mathrm{Y}$ \\
\hline 34 & Praia Maria Neném - Piúma/ES & M & $\mathrm{Y}$ \\
\hline
\end{tabular}

$\mathrm{F}=$ female; $\mathrm{M}=$ male; $\mathrm{U}=$ undetermined; $\mathrm{Y}=$ yes; $\mathrm{N}=$ no.

Chaloupka and Limpus (2005) did not find any significant differences in survival and recapture probability rates between males and females in the population of green turtles from the South of the Great Barrier Reef, Australia.

Thus, one could suggest there is a higher number of female individuals in the natural environment than males. However, in Brazil, the pivotal temperature for incubation of C. mydas eggs is still unknown (Almeida et al., 2011) and there are no records of studies that address differences of survival probabilities between sexes nor susceptibilities to diseases. Furthermore, little is known about migration patterns of juvenile turtles.
Macroscopic appearance of ovaries and testes from sea turtles has been described for all species. Macroscopic sex identification of juvenile turtles during necropsy by the means of gonad inspection is an easy and inexpensive method and therefore widely utilized in many studies (Lazar et al., 2008). In a study by the same author with individuals of the species Caretta caretta sexing accuracy for 99 turtles was $92.9 \%$, confirmed by gonadal histology.

In the present study, $100 \%$ of the viable samples had a correct macroscopic sex identification, which was confirmed by the observation of ovarian follicles and seminiferous tubules in ovaries and testicles, respectively. 
Macroscopic aspects observed in ovaries of $C$. mydas were similar to those described by many authors. In the prepubescent life stage, ovaries of juvenile marine turtles present previtellogenic follicles as tiny sphered inside the compact ovarian stroma (Miller and Limpus, 2003).

In relation to mean length and width of ovaries, some variations were observed in those measurements, although there was a moderate positive correlation between gonad length, CCL and body mass, which suggests there is a tendency for gonad growth as the animal grows.

According to microscopic assessment, all females were at prepubescent sexual maturation stage, identified by the presence of previtellinic follicles, compact stroma and the absence of atresic follicles, corpus luteum and corpus albicans. Miller and Limpus (2003) describe a classification for sexual maturity and reproductive stages based on the micro and macroscopic characterization of gonads and sexual structures. However, it does not consider the sequence of follicular development stages.

The sequence of follicular development stages has only been described for the marine species Eretmochelys imbricata, where a relation with sexual maturity and individual size was found (Pérez-Bermúdez et al., 2012). This correlation cannot be extrapolated to $C$. mydas for both species present diverse body characteristics through different life stages.

However, as described by Pérez-Bermúdez et al. (2012), oocyte diameter increases during the process of sexual maturation and may be utilized to stablish the stage of the life cycle.

Some authors have described a positive correlation between the largest oocyte diameter and CCL, but to date, no study could establish a correlation between turtle size and follicular development stage. Individuals that inhabit one same environment may have hatched in different moments and come from distinct origins and therefore present a different maturation stage. Beyond that, juvenile turtles (prepubescent) from both sexes may present the same carapace measurements, which makes CCL an inappropriate method to define sexual maturity.
Similarly to the females, macroscopic sexual determination for males was accurate, verified by histology of the testis. The smooth surface texture corroborates with the one described by Wyneken (2001) in young turtles. Testes from these individuals little varied in dimensions, with one exception only, one adult male, considered so for presenting CCL of $1.023 \mathrm{~m}$ and secondary sexual characteristics. The testicles from this individual presented a purple-greyish colour and cylindrical shape, similar to the description for C. caretta by Miller and Limpus (2003), with a volume notoriously increased compared to juveniles, in which the organ presented a flatter surface. Yet, histological exam was not possible in the adult turtle due to the evident autolysis of tissue sample.

In relation to the macro and microscopic assessment of the viable tissue samples, $100 \%$ of the turtles were classified as pre-pubescent according to Miller and Limpus (2003). Nevertheless, for this classification, only the macroscopic morphology of the tissue and histologically the presence of small seminiferous tubules was taken into account. Neither developmental histomorphometric alterations of the tubules, or changes in cellularity in these structures, especially in relation to the prepubescent and pubescent stages in male individuals, were considered.

In the present study, prevalence of spermatogonia followed by Sertoli cells and a small number of primary spermatocytes were observed in the seminiferous tubules and fibroblasts and Leydig cells in the interstitial space, constituted by loose connective tissue.

Otsuka et al. (2008) described only four cellular types: germ cells and Sertoli cells in the seminiferous tubules and; fibroblasts and Leydig cells in the interstice.

The author categorized the testicular development of C. mydas in six stages based on the appearance of the interstitial space and expansion of the seminiferous tubules.

According to this classification, considering tubular lumen and aspects of interstitial space, three individuals in the present study were classified as stage II (CCL: 0.302, 0.338 and $0.346 \mathrm{~m}$ ) and two turtles were in stage III (CCC 
0.364 and $0.436 \mathrm{~m}$ ). However, individuals classified as stage II presented tubule diameter $(46.55 \mu \mathrm{m}, 33.15 \mu \mathrm{m}$ and $36.20 \mu \mathrm{m}$, respectively) smaller than the mean diameter described by the author for animals in that stage of gonad development (approximately $60.00 \mu \mathrm{m}$ ).

The morphometric analysis of seminiferous tubules showed a positive correlation between tubule diameter and tubular lumen and between tubule diameter and CCL.

During the gonadal histomophormetric evaluation in the present study, from turtles stranded on the coast of Espírito Santo State, Brazil, no findings suggested morphological, structural nor cellular composition alterations of the tissues.

Marine turtles were proposed to be good biological indicators according to Lyons et al. (2010) due to their long life span, trophic level and mobility patterns, which allows for their interaction with pollution over extended areas (Camacho et al., 2014).

Furthermore Hamann et al. (2010) state that for conservation of the marine species, assessing specific impacts that pollutants exercise on sea turtles must be considered as a research priority and demands further investigation.

Considering the importance of the reproductive activity in the perpetuation of any given species, especially when one is classified as vulnerable and threatened of extinction, to stablish the sequence of follicular maturation in females of Chelonia mydas, as well as categorize the stages of testicular development is essential for comprehensive understanding of their reproductive function. Nonetheless, very little is known about the impact and influence inorganic toxic agents and other xenobiotic compounds exercise on the reproductive system of these animals, even though negative impacts and damages have already been reported in gonads and reproductive activity of some other species. Therefore, further studies and deeper investigation are required for improved understanding of the matter and to elaborate and orientate planning and implementation of mitigating actions.

\section{CONCLUSION}

This study revealed that gonad development of sea turtles from the species Chelonia mydas is proportional to individual growth. Sexual determination by macroscopic observation of gonads is a reliable identification method for prepubescent specimens of $C$. mydas.

\section{ACKNOWLEDGEMENTS}

Thanks to CTA Meio Ambiente for allowing collecting samples and pertinent data. This work was supported by the Federal University of Espírito Santo through the Institutional Program for Scientific Research Initiation and by Fundação de Amparo à Pesquisa do Espírito Santo (FAPES) in form of scholarships.

\section{REFERENCES}

AGUIRRE, A.A.; BALAZS, G.H.; ZIMMERMAN, B.; GALEY, F.D. Organic contaminants and trace metals in the tissues of green turtles (Chelonia mydas) afflicted with fibropapillomas in the Hawaiian Islands. Mar. Pollut. Bull., v.28, p.109-114, 1994.

AITKEN, R.N.C.; SOLOMON, S.E.; AMOROSO, E.C. Observations on the histology of the ovary of the costa rican green turtle, Chelonia mydas L. J. Exp. Mar. Biol. Ecol., v.24, p.189-204, 1976.

ALMEIDA, A.P.; SANTOS, A.J.B.; THOMÉ, J.C.A. et al. Avaliação do estado de conservação da tartaruga marinha Chelonia mydas (Linnaeus, 1758) no Brasil. Biodivers. Bras., v.1, p.12-19, 2011.

ANSARI, B.A.; KUMAR, K. Malathion toxicity: effect on the ovary of the zebra fish Brachydanio rerio (Cyprinidae). Int. Rev. Ges. Hydrobiol., v.72, p.517-528, 1987.

BRASIL. Ministério do Meio Ambiente. Portaria $\mathrm{n}^{\circ} 444$, de 17 de dezembro de 2014. Reconhece como espécies da fauna brasileira ameaçadas de extinção aquelas constantes na Lista Nacional Oficial de Espécies da Fauna Ameaçadas de Extinção. Diário Oficial da União, p.121-126. 2014.

CAMACHO, M.; BOADA, L.D.; ORÓS, J. et al. Monitoring organic and inorganic pollutants in juvenile live sea turtles: results from a study of Chelonia mydas and Eretmochelys imbricata in Cape Verde. Sci. Total Environ., v.481, p.303-310, 2014.

CAMACHO, M.; LUZARDO, O.P.; BOADA, L.D. et al. Potential adverse health effects of persistent organic pollutants on sea turtles: evidences from a cross-sectional study on Cape Verde loggerhead sea turtles. Sci. Total Environ., v.458-460, p.283-289, 2013 
CERIANI, S.; WYNEKEN, J. Comparative morphology and sex identification of the reproductive system in formalin-preserved sea turtle specimens. Zoology, v.141, p.179-187, 2007.

CHALOUPKA, M.; LIMPUS, C. Estimates of sexand age-class-specific survival probabilities for a southern great barrier reef green sea turtle population. Mar. Biol., v.146, p.1251-1261, 2005.

EL-EBIARY, E.H.; WAHBI, O.M.; EL-GREISY, Z.A. Influence of dietary cadmium on sexual maturity and reproduction of red tilapia. Egypt. J. Aquat. Res., v.39, p.313-317, 2013.

GROSSMAN, A.; MENDONÇA, P.; COSTA, M.R.; BELLINI, C. Morphometrics of the green turtle at the Atol das Rocas Marine Biological Reserve, Brazil. Mar. Turtle Newsl., v.118, p.12-13, 2007.

HAMANN, M.; GODFREY, M.H.; SEMINOFF, J.A. et al. Global research priorities for sea turtles: informing management and conservation in the $21^{\text {st }}$ century. Endang. Species Res., v.11, p.245-269, 2010.

INTERNATIONAL union for conservation of nature and natural resources. The IUCN Red List of Threatened Species. Version 2013.2. Available in: $<$ http://www.iucnredlist.org $>$. Acessed in: 2 May 2014.

KELLER, J.M.; MCCLELLAN-GREEN, P.D.; KUCKLICK, J.R. et al. Effects of organochlorine contaminants on loggerhead sea turtle immunity: comparison of a correlative field study and in vitro exposure experiments. Environ. Health Perspect., v.114, p.70-76, 2006.

KIME, D.E. The effects of pollution on reproduction of fish. Rev. Fish Biol. Fisher., v.5, p.52-96, 1995.

KORTENKAMP, A.; MARTIN, O.; FAUST, M. et al. State of the art assessment of endocrine disrupters: Final Report. Eur. Union J., 2011. Available in: $<$ http://ec.europa.eu/environment/chemicals/endocrine /pdf/sota_edc_final_report.pdf $>$. Accessed in: 3 May 2014.

LAZAR, B.; LACKOVIC, G.; CASALE, P. et al. Histological validation of gonad gross morphology to sex juvenile loggerhead sea turtles (Caretta caretta). Herpetol. J., v.18, p.137-140, 2008.

LYONS, B.P.; THAIN, J.E.; STENTIFORD, G.D. et al. Using biological effects tools to define good environmental status under the European Union Marine strategy framework directive. Mar. Pollut. Bull., v.60, p.1647-1651, 2010.
MASCARENHAS, R.; SANTOS, R.; ZEPPELINI, D. Stranded sea turtles on the coast of Paraíba, Brazil. Mar. Turtle Newsl., v.107, p.13-14, 2005.

MILLER, J.D.; LIMPUS, C.J. Ontogeny of Marine Turtles gonads. In: LUTZ, P.L.; MUZIK, J.A.; WYNEKEN, J. (Eds). The biology of sea turtles. Boca Raton: CRC Press, 2003. v.2, p.199-224.

OTSUKA, S.; SUZUKI, M.; KAMEZAKI, N. et al. Growth-related changes in histology and immunolocalization of steroid hormone receptors in gonads of the immature male green turtle (Chelonia mydas). J. Exp. Zool., v.309, p.166-174, 2008.

PÉREZ, E.; RUIZ, A.; ESPINOSA, G.; LEE, I. Histología gonadal y criterios fenotípicos de maduración en las tortugas marinas Chelonia mydas y Eretmochelis imbricata (Testudines: Cheloniidae) de Cuba. Rev. Biol. Trop., v.58, p.287-298, 2010.

PÉREZ-BERMÚDEZ, E.; RUIZ-URQUIOLA, A.; LEE-GONZALEZ, I. et al. Ovarian follicular development in the hawksbill turtle (Cheloniidae: Eretmochelis imbricata L.). J. Morphol., v.273, p.1338-1352, 2012.

POLI, C.; LOPEZ, L.C.S.; MESQUITA, D.O. et al. Patterns and inferred proccesses associated with sea turtle strandings in Paraíba State, Northeast Brazil. Braz. J. Biol., v.74, p.283-289, 2014.

RAM, R.N.; SATHYANESAN, A.G. Effect of a mercurial fungicide on the gonadal development of the teleostean fish Channa punctatus (Bloch). Ecotoxicol. Environ. Safety, v.11, p.352-360, 1986.

RAM, R.N.; SATHYANESAN, A.G. Effects of longterm exposure to cythion on the reproduction of the teleost fish, Channa punctatus (Bloch). Environ. Pollut., v.44, p.49-60, 1987.

VICTOR, B.; MAHALINGAM, S.; SAROJINI, R. Toxicity of mercury and cadmium on oocyte differentiation and vitellogenesis of the teleost, Lepidocephalichthys thermalis (BIeeker). J. Environ. Biol., v.7, p.209-214, 1986.

WIBBELS, T. Critical approaches to sex determination in sea turtles. In: LUTZ, P.L.; MUZIK, J.A.; WYNEKEN, J. (Eds.). The biology of sea turtles, Boca Raton: CRC Press, 2003. v.2, p.103-134.

WYNEKEN, J. The anatomy of sea turtles. [s.1.]: U.S. Department of Commerce NOAA-470, 2001. 177p. (Technical Memorandum NMFS-SEFSC). 